\title{
MINERALOGICAL AND GEOCHEMICAL CHARACTERIZATION OF ZEOLITES IN ALBANIAN OPHIOLITIC PLAGIOGRANITES
}

\author{
Goga Beqiraj E. ${ }^{1}$, Muller F. ${ }^{2}$ and Beqiraj A. \\ ${ }^{I}$ Polytechnic University of Tirana, Faculty of Geology and Mines, Rruga Elbasani, \\ ea_beqiraj@yahoo.com \\ ${ }^{2}$ Institut des Sciences de la Terre d'Orleans, Rue de la Férollerie Orleans, Cedex 2, France
}

\begin{abstract}
The plagiogranites, that represent the uppermost part of the plutonic complex of the Albanian ophiolites, are intensively altered. They crop out in the north - eastern sectors of the Albanian ophiolitic complex presenting intrusive contacts with volcanic and gabbroic rocks. The zeolite, that is a typically secondary mineral, has filled thin veins and/or small vesicles of the rock. From the XRD, EMPA and microscopic analyses it is concluded that this zeolite belongs to the laumontite - leonhardite (LAU) series.

Keywords: Laumontite, leonhardite, zeolites, plagiogranites, Kimza-Tuci.

\section{Пврі́ $\eta \psi \eta$}

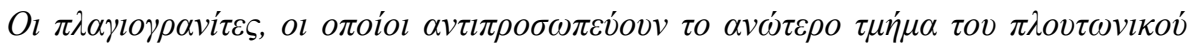

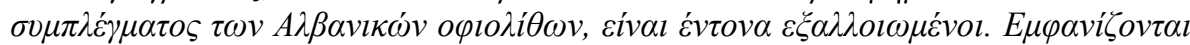

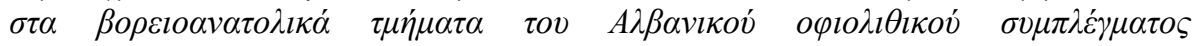

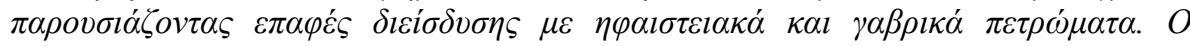

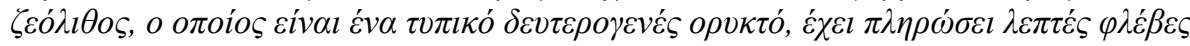

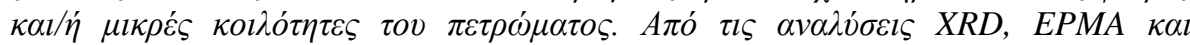

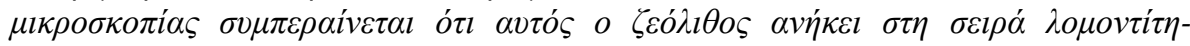

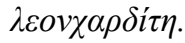

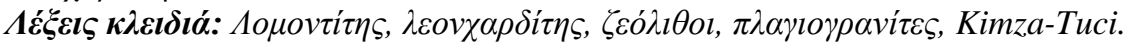

\section{Introduction}

It is well known that zeolites are framework silicates consisting of interlocking $\mathrm{SiO}_{4}$ and $\mathrm{AlO}_{4}$ tetrahedrons. In order to be a zeolite the ratio $(\mathrm{Si}+\mathrm{Al}) / \mathrm{O}$ must be equal to $1 / 2$. The alumino-silicate structure is negatively charged and attracts the positive cations that reside within it. Unlike most other tectosilicates, zeolites have large vacant spaces or cages in their structures that allow space for large cations such as sodium, potassium, barium and calcium and even relatively large molecule and cation groups such as water, ammonia, carbonate ions and nitrate ions (Gottardi and Galli, 1985; Baerlocher et al., 2007). Therefore, zeolites were known to be able to act as ion exchangers of high ion exchange capacity (Soulaymana et al., 2004). 
The zeolites in Albanian ophiolites are related with medium-acid volcanic rocks and with plagiogranites. Plagiogranites constitute the upper part of the plutonic sequence of the Albanian ophiolites and crop out among volcanic rocks (low-Ti basalts, andesites and dacites) (Shallo, 1995). Kimza-Tuci plagiogranitic unit consists of tonalites and trondhjemites. This unit is associated with microdiorites of small area.

The zeolites of the Kimza-Tuci plagiogranites have been scarcely studied (Kati, 1967). They occur as small and thin veins and/or vesicles within the above mentioned rocks. This study aims to further advance their mineralogical-chemical characterization based on the new analytical data.

\section{Geological setting and sampling}

The plagiogranites of Kimza-Tuci are located in the E-type ophiolites (Bebien et al., 1997) in the north-eastern part of the Jurassic Mirdita ophiolitic complex, Albania (Fig. 1). The later represents an important segment of the Tethyan ophiolites in the Alpine orogenic system where two belts are distinguished: the "lherzolitic" western belt and "harzburgitic" eastern belt which show MORB and SSZ affinities, respectively (Shallo, 1992; Robertson and Shallo, 2000; Shallo and Dilek, 2003; Bortolotti et al., 2005; Dilek et al., 2007).

Western belt ophiolites compose an incomplete section which consists, from the bottom to the top, of ultramafic sequence (lherzolite-harzburgite, plagioclase lherzolite, plagioclase dunite, rare amphibole peridotite), overlain by limited and thin plutonic sequence (composed of troctolite, olivine gabbro, ferrogabbro, gabbro, rare amphibole gabbro and plagiogranite) and massive and pillow basalt, basalt-andesitic MORB type lavas (Shallo, 1994). On the contrary, a complete section is characteristic for the eastern belt ophiolite which consists of harzburgite, interbedded harzburgitedunite, massive dunite, overlain by gabbronoritic sequence (layered and massive gabbronorite, gabbro, amphibole gabbro, quartz diorite and plagiogranite), on which lie a sheeted dyke complex and a basalt-dacitic (basalt, basalt-andesite, boninite, andesite, dacite, quartz dacite, rhyodacite) volcanic sequence (Shallo, 1994).

Quartz diorites and plagiogranites constitute the upper part of the plutonic sequence of the Albanian ophiolites and they are often accompanied by sheeted dyke complexes. They consist of plagiogranite and quartz diorite, while lateral sectors of the above magmatic bodies are represented by microdiorite. The plagiogranites contain zoned plagioclase, quartz, calcic pyroxene, amphibole and magnetite. Secondary alteration results in the development of albite, actinolite, chlorite, epidote and zeolite.

Seven samples were collected from plagiogranitic rocks of Kimza-Tuci region (Fig.1) which crop out among volcanic rocks (low-Ti basalts, andesites and dacites) and are intruded by low-Ti basaltic and andesitic dykes (Shallo, 1995). Kimza plagiogranitic unit consists of tonalities and trondhjemites associated with microdiorites of small area. These rocks contain a normally-zoned plagioclase $\left(\mathrm{An}_{50-15}\right)$, augite $\left(\mathrm{Wo}_{41} \mathrm{En}_{39} \mathrm{Fs}_{20}\right)$, ferro- edenitic amphibole, quartz, magnetite, ilmenite and abundant apatite (Bebien et al., 1997).

Based on the geochemical data the tonalite - trondhjemite of Kimza shows a clear magmatic affinity with those from suprasubduction zone and are similar with sheeted dyke complexes and basaltandesite volcanic rocks (Bebien et al., 1995; Shallo, 1995). These leucocratic plutonic rocks reflect the diversity of the magmatic processes involved in the development of oceanic lithospheres near subduction zones (Bebien et al., 1997). ${ }^{40} \mathrm{Ar}-{ }^{39} \mathrm{Ar}$ radiometric ages of the plagiogranite and quartzdiorite intrusions show rather similar ages of 160 Ma to 165 Ma (Dilek et al., 2001, 2007).

\section{Methods of study}

Zeolite enriched samples were obtained by purification processes based on greater friability and lower density (de' Gennaro and Franco, 1979; de' Gennaro and Langella, 1996). Samples were 
characterized by thin X-fluoresence, ICP-MS, thin section petrography, electron microprobe analysis (EMPA), X-ray diffraction (XRD).

Mineralogy of bulk and separated material was examined by X-ray diffraction using transmission geometry. The patterns were recorded in a $5^{\circ} 2 \theta$ to $120^{\circ} 2 \theta$ interval using a curved detector INEL, CPS 120 and a Co anticathode $(\lambda \mathrm{CoK} \alpha 1=0.70926 \AA)$. The powder samples were placed in capillary tubes $(0.5 \mathrm{~mm})$. Chemical analyses of zeolites and associated minerals were performed using CAMECA (CAMEBAX type) electron microprobe under the following operating conditions: accelerating voltage of $20 \mathrm{kV}$, sample current of $10 \mathrm{nA}$ and a beam diameter $7 \mu \mathrm{m}$ to $10 \mu \mathrm{m}$. Microscopic observation was done using a Leitz Wetzlar microscope.

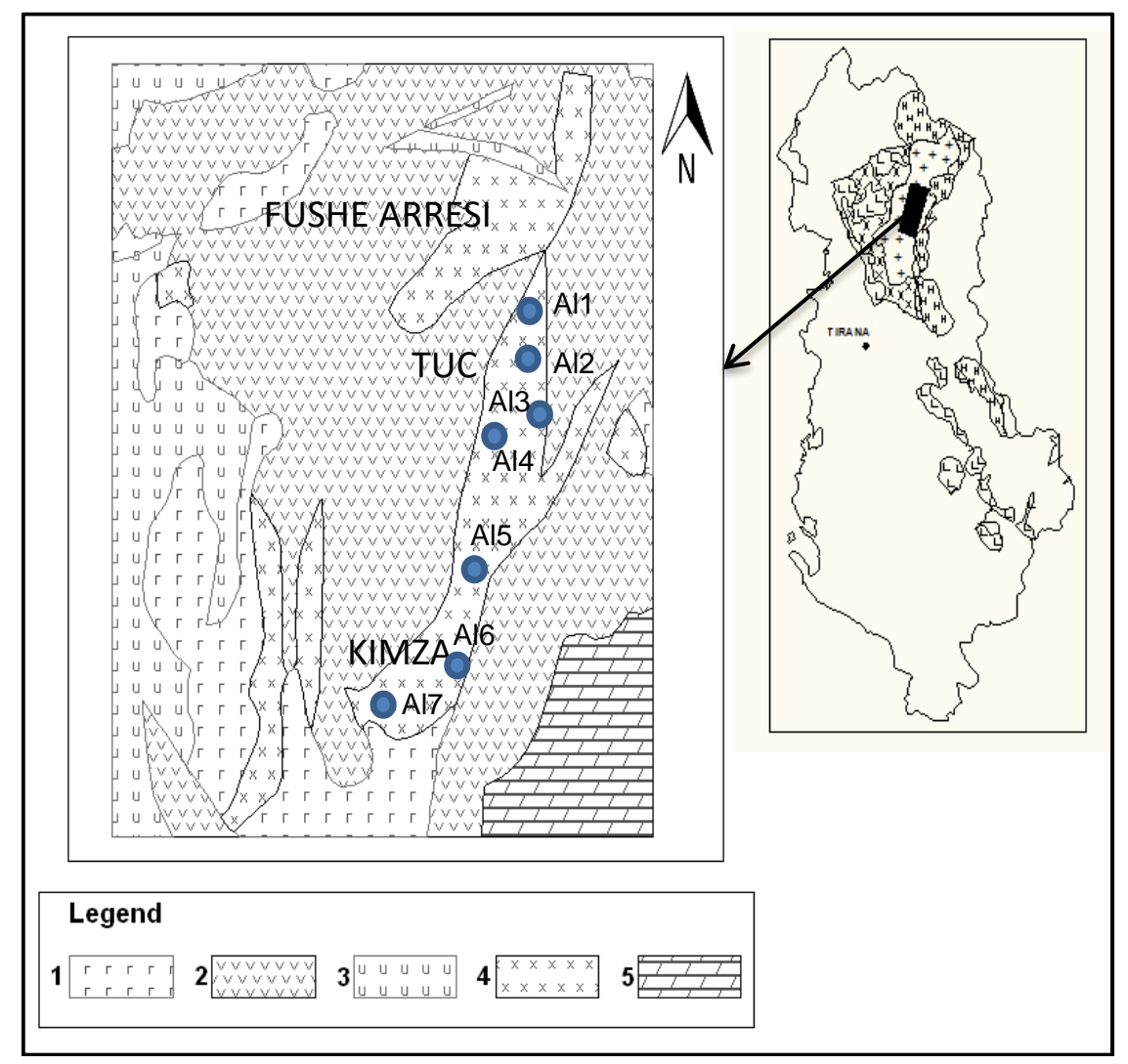

Figure 1 - Geological sketch of Kimza-Tuci region. Legend: 1. Gabbro, 2. Basalt - andesite, 3. Ultramafic rock, 4. Plagiogranite, 5. Limestone.

In particular, we focused on EMPA data which allow precise point analysis and thus correct characterization of minerals (Reed, 2005). This is important since many minerals show a wide variability in crystal size and composition and are not easy to be accurately determined with other methods. For example, feldspars, amphiboles or micas can incorporate many elements, which might be distinctive of certain rock types and genetic development. Apart from the methodological advantages, one of the strengths of the electron microprobe is the effective combination of backscattered electron images (BSEI) and quantitative analyses (Ionescu et al., 2011).

\section{Results and discussion}

The zeolitization represents one of the most developed secondary processes that affected the plagiogranitic rocks, thus generating the so-called mineralized zone (Kati, 1965). Macroscopically, the zeolitized plagiogranites are white to rouse and they are often friable. The zeolites occur as small 
and thin veins and/or vesicles within the above mentioned rocks and, in some cases they cut the sulphide mineralized dykes. The thickness of the zeolite veins ranges from a few $\mathrm{mm}$ up to $2-3 \mathrm{~cm}$.

\begin{tabular}{|c|c|c|c|c|c|c|c|}
\hline \multicolumn{8}{|c|}{$\begin{array}{l}\text { Table } 1 \text { - Chemical analysis of zeolites from the Kimza-Tuci } \\
\text { plagiogranites (oxides are in wt\%, while REE in ppm). }\end{array}$} \\
\hline Sample & Al1 & $\mathrm{Al} 2$ & $\mathrm{Al} 3$ & $\mathrm{Al} 4$ & A15 & Al6 & $\mathrm{Al} 7$ \\
\hline $\mathrm{SiO}_{2}$ & 68.98 & 69.71 & 67.63 & 50.79 & 55.10 & 62.99 & 53.04 \\
\hline $\mathrm{Al}_{2} \mathrm{O}_{3}$ & 13.05 & 11.84 & 12.03 & 18.35 & 18.80 & 13.59 & 20.47 \\
\hline $\mathrm{Fe}_{2} \mathrm{O}_{3}$ & 5.58 & 4.53 & 6.23 & 7.82 & 3.58 & 5.62 & 2.18 \\
\hline $\mathrm{MnO}$ & 0.059 & 0.026 & 0.093 & 0.133 & 0.031 & 0.083 & 0.034 \\
\hline $\mathrm{MgO}$ & 0.86 & 0.53 & 1.04 & 3.06 & 1.15 & 0.77 & 0.45 \\
\hline $\mathrm{CaO}$ & 2.81 & 5.15 & 4.75 & 8.04 & 8.99 & 5.41 & 10.93 \\
\hline $\mathrm{Na}_{2} \mathrm{O}$ & 4.62 & 1.09 & 1.09 & 0.29 & 0.37 & 1.54 & 0.06 \\
\hline $\mathrm{K}_{2} \mathrm{O}$ & 0.17 & 0.09 & 0.09 & 0.16 & 0.21 & 0.41 & 0.16 \\
\hline $\mathrm{TiO}_{2}$ & 0.467 & 0.351 & 0.427 & 0.587 & 0.301 & 0.376 & 0.153 \\
\hline $\mathrm{P}_{2} \mathrm{O}_{5}$ & 0.10 & 0.07 & 0.09 & 0.05 & 0.05 & 0.08 & 0.02 \\
\hline LOI & 3.17 & 6.65 & 6.38 & 11.12 & \begin{tabular}{|l}
11.76 \\
\end{tabular} & 8.19 & 12.82 \\
\hline Total & 99.87 & 100.03 & 99.84 & 100.4 & 100.34 & 99.06 & 100.31 \\
\hline $\mathrm{Ba}$ & 13 & 3 & $\mathrm{Nd}$ & 4 & 4 & 7 & $\mathrm{Nd}$ \\
\hline $\mathrm{Sr}$ & 38 & 32 & 42 & 68 & 69 & 27 & 59 \\
\hline $\mathrm{Y}$ & 37 & 34 & 28 & 21 & 17 & 39 & 6 \\
\hline $\mathrm{Zr}$ & 105 & 58 & 50 & 39 & 31 & 69 & 32 \\
\hline $\mathrm{V}$ & 40 & 17 & 19 & 261 & 76 & 8 & 52 \\
\hline $\mathrm{Co}$ & 9 & 5 & 7 & 22 & 10 & 5 & 13 \\
\hline $\mathrm{Cr}$ & 129 & 59 & 91 & 39 & 27 & 44 & 15 \\
\hline $\mathrm{Hf}$ & 3.4 & 1.7 & 2 & 1.1 & 1 & 2.1 & $\mathrm{Nd}$ \\
\hline $\mathrm{Sc}$ & 16.7 & 15.8 & 19.2 & 27.9 & 14.4 & 17.2 & 7.9 \\
\hline $\mathrm{La}$ & 3.3 & 4.7 & 3.8 & 2.4 & 2 & 4.8 & 1 \\
\hline $\mathrm{Ce}$ & 10 & 12 & 11 & 6 & 5 & 13 & $\mathrm{Nd}$ \\
\hline $\mathrm{Nd}$ & 8 & 8 & 5 & $\mathrm{Nd}$ & $\mathrm{Nd}$ & 9 & $\mathrm{Nd}$ \\
\hline $\mathrm{Sm}$ & 2.9 & 2.6 & 2.3 & 1.6 & 1.5 & 2.7 & 0.6 \\
\hline $\mathrm{Eu}$ & 0.8 & 0.6 & 0.7 & 0.6 & 0.4 & 0.8 & 0.2 \\
\hline $\mathrm{Tb}$ & $\mathrm{Nd}$ & 0.9 & 0.5 & $\mathrm{Nd}$ & $\mathrm{Nd}$ & 0.7 & $\mathrm{Nd}$ \\
\hline $\mathrm{Yb}$ & 4.8 & 4.1 & 4 & 2.6 & 2.2 & 4.5 & 1 \\
\hline $\mathrm{Lu}$ & 0.72 & 0.62 & 0.6 & 0.41 & 0.33 & 0.69 & 0.15 \\
\hline
\end{tabular}

Both major and trace elements were analyzed (Table 1). In the $\mathrm{SiO}_{2}-\mathrm{FeO}_{\mathrm{t}} / \mathrm{MgO}$ plot (Fig. 2) all the plagiogranites of the Kimza-Tuci region plot in the tholeiitic field showing a wide range of $\mathrm{SiO}_{2}$ (50-70 wt\%). In addition, the $\mathrm{FeO}_{\mathrm{t}} / \mathrm{MgO}\left(\mathrm{FeO}_{\mathrm{t}}=\right.$ total iron) is high and increases with increasing $\mathrm{SiO}_{2}$ content. All the samples present very low $\mathrm{K}_{2} \mathrm{O}$ content. They show positive $\mathrm{MgO}$ vs. $\mathrm{TiO}_{2}$ and Co correlation and poor correlation of $\mathrm{MgO}$ vs. $\mathrm{Cr}$, but no correlation was observed between $\mathrm{MgO}$ and $\mathrm{CaO}, \mathrm{Al}_{2} \mathrm{O}_{3}, \mathrm{Hf}, \mathrm{Zr}$ and $\mathrm{Y}$. Geochemically, they are not very different from ocean ridge granites (Bebien et al., 1997; Pierce et al., 1984).

REE abundances of the Kimza-Tuci plagiogranites show two well differentiated patterns (Fig. 3). The first belongs to samples Al1, Al3 and Al5 which exhibit slightly LREE-depleted patterns, similar to plagiogranites from Cyprus and Oman ophiolites (Aldiss, 1981; Gillis and Coogan, 2002). Both show geochemical MORB affinity. On the contrary, the second group of samples (A12, Al4 and A16) exhibits highly HREE depleted patterns. Crystal fractionation of amphibole or partial melting of amphibolite can cause the enrichment of LREE in plagiogranite melt, because amphibole 
has high partition coefficients for heavy REE (HREE) (Green, 1994). Finally, REE pattern of sample Al7 doesn't fit neither with the first group of samples nor with the second one.

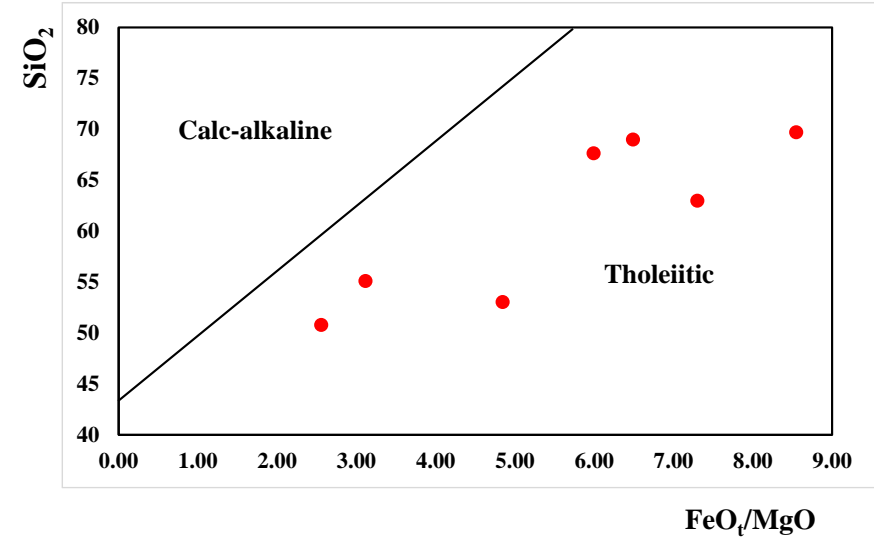

Figure 2 - Plot of $\mathrm{SiO}_{2}$ versus $\mathrm{FeO}_{t} / \mathrm{MgO}$ for lavas and dikes of the WMO and EMO. The boundary line between tholeiitic and calc-alkaline rock types is from Miyashiro (1974).

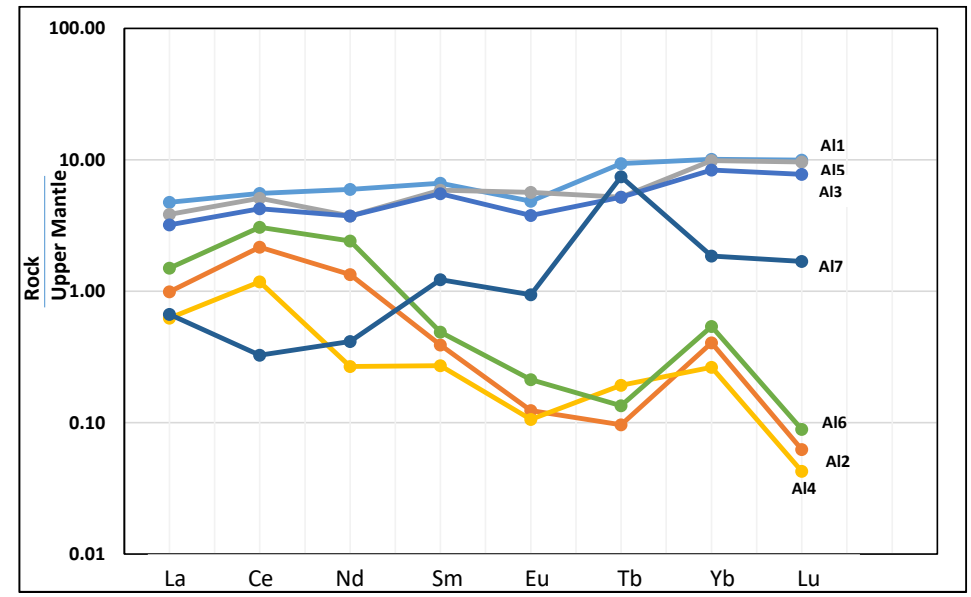

Figure 3 - Upper Mantle-normalized REE pattern of the plagiogranites. Normalized Upper Mantle values are taken from McDonough and Frey (1989).

The difference between the two groups of plagiogranites is evidence that ophiolites do not represent all kinds of ocean crust and that a greater range of magma compositions and/or conditions of magmatic differentiation is represented by the ocean crust (Aldiss, 1981).

Based on XRD, EMPA, DTA and optical observation the mineralogical composition of the studied plagiogranites mainly consists of plagioclase and quartz (55-60\%), followed by LAU-type zeolite (30-35\%) and subordinate amphibole and chlorite (10\%) (Fig. 4).

From the thin section petrography it was found that plagiogranites are fine to medium-grained rocks with subhedral granular and intergranular textures that contain plagioclase, quartz and minor amounts of amphibole and chlorite. In addition scarce quantities of epidote and magnetite are observed. Zeolites are represented by laumontite which belongs to two structural types: the first type was formed by replacement of albite and the second was formed through filling of the fractures and veins. They are slightly colored (grey, beige). Biotite is partly transformed into chlorite. 


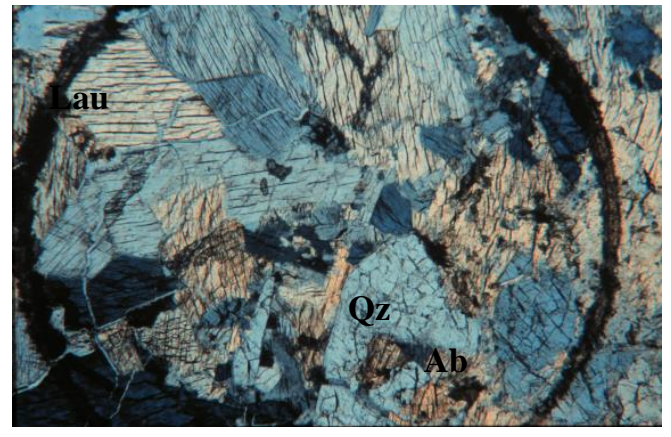

$\mathbf{a}$

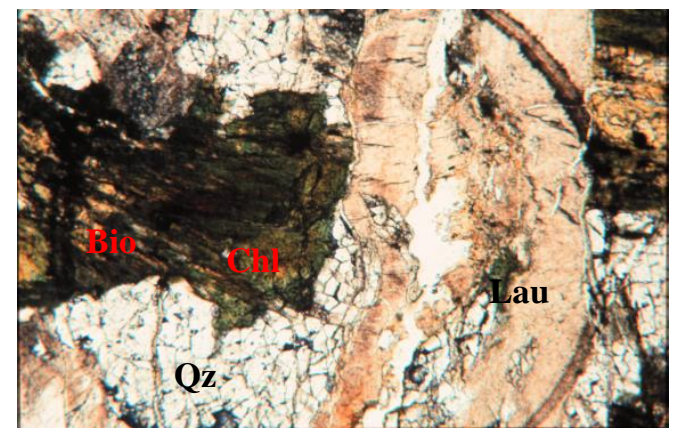

b

Figure 4 - Microphotographs from plagiogranites showing the zeolitization process. (a. Zeolite-free plagiogranite - PL, 6.3x; b. Zeolite-bearing plagiogranite - PL, 6.3x; Lau=Laumontite; Qz=Quartz; Ab=Albite; Bio=Biotite; Chl=Chlorite).

Fig. 2 shows X-ray diffraction of three (of seven samples analyzed by XRD) powdered zeolitebearing plagiogranite samples (Al2, Al3, Al7). X-ray diffraction analysis revealed the presence Laumontite-Leonhardite series which corresponds to peaks $d=9.41 \AA$ and $d=4.15 \AA$. As it can be seen by diffraction spectra of the samples studied, there is no differences between them with respect to zeolite phase.

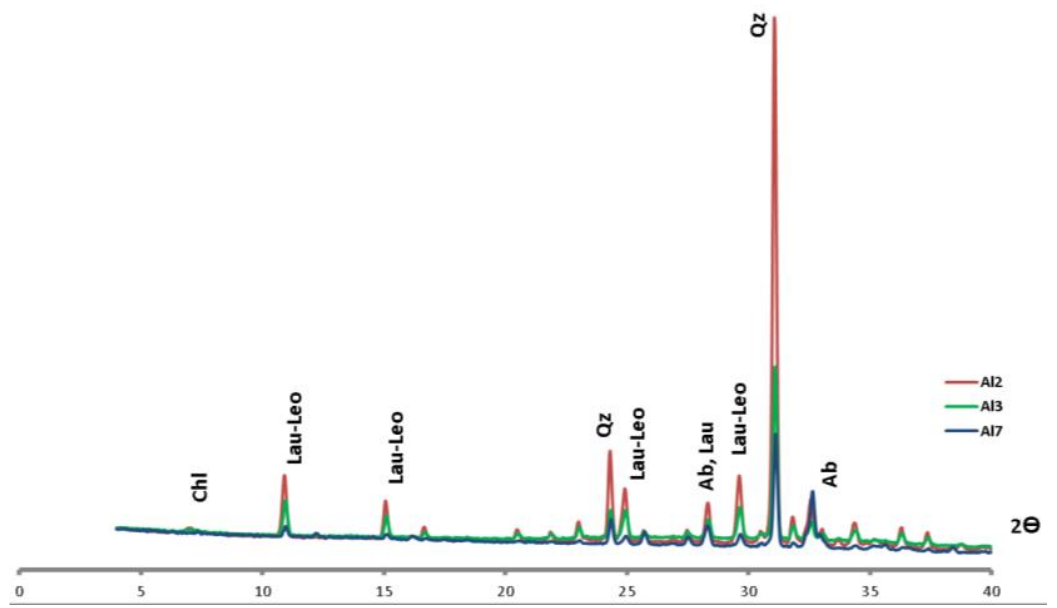

Figure 5 - X-ray diffraction pattern of Al2, Al3 and Al7 samples (Chl - chlorite; Lau-Leo Laumontite-Leonhardite; Qz - Quartz; Ab - Albite).

The non-zeolitic phase consists of quartz which corresponds to peaks $d=3.34 \AA$ and $d=4.25 \AA$; albite ( $d=3.65 \AA$ and $3.18 \AA$ ).It was also observed the presence of chlorite that corresponds to very weak peaks $(\mathrm{d}=14.28 \AA)$ in the sample $\mathrm{Al} 3, \mathrm{Al} 7$ and are quite similar with corresponding peaks in samples $\mathrm{Al}$ 4, Al5 and Al6 (not shown).

From the EMPA analytical data (Table 2) it is concluded that the chemical composition of laumontite is normally near to its stoichiometric formula: $\mathrm{Ca}_{0.9} \mathrm{Al}_{2.1} \mathrm{Si}_{4.0} \mathrm{O}_{12} \quad 4 \mathrm{H}_{2} \mathrm{O}$ (Al1), $\mathrm{Ca}_{1.0} \mathrm{Al}_{2.0} \mathrm{Si}_{4.0} \mathrm{O}_{12} 4 \mathrm{H}_{2} \mathrm{O}$ (Al2, $\mathrm{Al} 3$ ), $\mathrm{Ca}_{0.9} \mathrm{Al}_{2.0} \mathrm{Si}_{4.1} \mathrm{O}_{12} 4 \mathrm{H}_{2} \mathrm{O}$ (Al4, Al5, Al6, Al7). The content (as a.f.u.) of the principal constituents ranges within the intervals $14.90-16.20 \%, 7.91-8.49 \%$ and 2.8 $3.8 \%$ for $\mathrm{Si}, \mathrm{Al}$ and $\mathrm{Ca}$, respectively. All the analyses show the presence of a Ca highly rich 
laumontite as it could be expected from the strong calc-alkaline affinity of the host rocks (plagiogranites).

\begin{tabular}{|c|c|c|c|c|c|c|c|}
\hline \multicolumn{7}{|c|}{ Table 2 - Selected microprobe analysis of LAU zeolites from the } \\
studied samples (wt\%). \\
\hline Sample & $\mathrm{Al1}$ & $\mathrm{Al} 2$ & $\mathrm{Al} 3$ & $\mathrm{~A} 14$ & $\mathrm{~A} 115$ & $\mathrm{Al} 6$ & $\mathrm{Al}$ \\
\hline $\mathrm{SiO} 2$ & 47.94 & 53.48 & 53.12 & 51.22 & 51.58 & 51.05 & 51.71 \\
\hline $\mathrm{FeO}$ & 0.00 & 0.075 & 0.15 & 0.00 & 0.11 & 0.49 & 0.00 \\
\hline $\mathrm{Na} 2 \mathrm{O}$ & 0.027 & 0.00 & 0.04 & 0.058 & 0.02 & 0.01 & 0.00 \\
\hline $\mathrm{K} 2 \mathrm{O}$ & 0.125 & 0.101 & 0.12 & 0.42 & 0.45 & 0.44 & 0.14 \\
\hline $\mathrm{A} 12 \mathrm{O} 3$ & 21.74 & 23.049 & 22.44 & 21.48 & 21.70 & 21.31 & 21.72 \\
\hline $\mathrm{MnO}$ & 0.098 & 0.00 & 0.02 & 0.00 & 0.014 & 0.00 & 0.02 \\
\hline $\mathrm{MgO}$ & 0.00 & 0.00 & 0.00 & 0.00 & 0.00 & 0.44 & 0.00 \\
\hline $\mathrm{CaO}$ & 10.65 & 11.19 & 11.24 & 10.62 & 10.53 & 10.37 & 10.88 \\
\hline $\mathrm{TiO} 2$ & 0.00 & 0.00 & 0.04 & 0.033 & 0.00 & 0.00 & 0.00 \\
\hline $\mathrm{Total}$ & 80.58 & 87.90 & 87.18 & 83.83 & 84.41 & 84.13 & 84.47 \\
\hline
\end{tabular}

\section{Conclusions}

The plagiogranitic rocks from Kimza-Tuci region, northern Albania, are intensively altered and contain veins and vesicles filled with zeolites. Their mineralogical composition consists of plagioclase and quartz (55-60\%), followed by zeolites (30-35\%) and subordinate amphibole and chlorite (10\%).

They show geochemical signatures that are similar to those of oceanic granites.

The existing zeolite belongs to the LAU type where the Ca highly rich laumontite predominates as it could be expected from the strong calc-alkaline affinity of the host rocks (plagiogranites).

\section{Acknowledgments}

We appreciate the help of Dr. Tonin Deda who accompanied us during the sampling.

\section{References}

Aldiss, D.T., 1981. Plagiogranites from the ocean crust and ophiolites, Nature, 289, 577-579.

Baerlocher, Ch., McCusker and Olson, D.H., 2007. Atlas of zeolite framework types, Sixth Revised Edition, Elsevier, 405 pp.

Bebien, J., Shallo, M. and Karadumi, A., 1995. Intrusive ultramafic rocks in Albanian ophiolites, EUG-8.

Bébien, J., Dautaj, N., Shallo, M., Turku, I. and Barbarin, B., 1997. Diversity of ophiolitic plagiogranites: the Albanian example, Comptes Rendus de l'Academie des Sciences Series IIA, Earth and Planetary, 324, 875-889.

Bish, D.L. and Ming, D.W., 2001. Natural zeolites: Occurrence, Properties, Applications, Reviews in Mineralogy and Geochemistry, 45, USA, 654 pp.

Bortolotti, V., Marroni, M., Pandolfi, L. and Principi, G., 2005. Mesozoic to Tertiary tectonic history of the Mirdita ophiolites, northern Albania, Island Arc, 14, 471-493.

de' Gennaro, M. and Franco, E., 1979. Arrichimento e separazione delle zeoliti di rocce piroclestiche, Ind. Minerals, 30, 329-336.

de' Gennaro, M. and Langella A., 1996. Italian zeolitized rocks of technological interest, Miner. Deposita, 31, 452-472. 
Dilek, Y., Furnes, H. and Shallo, M., 2007. Geochemistry of the Jurassic Mirdita Ophiolite (Albania) and the MORB to SSZ evolution of a marginal basin oceanic crust, Lithos, 01618, $36 \mathrm{pp}$.

Gillis, K.M. and Coogan, L.A., 2002. Anatectic migmatites from the roof of an ocean ridge magma chamber, J. Petrology, 43, 2075-2095.

Green, 1994. Experimental studies of trace-element partitioning applicable to igneous petrogenesis - Sedona 16 years later, Chemical Geology, 117, 1-36.

Gottardi, G. and Galli, E., 1985. Natural Zeolites, Springer, Editors, A.EI Goresy, W von Engelhardt, T. Hahn. 391 pp.

Ionescu, C., Hoeck, V. and Ghergari, L., 2011. Electron microprobe analysis of ancient ceramics: A case study from Romania, Appl. Clay Science, 53(3), 466-475.

Kati, P., 1965. Ceolitizimi i shkembinjve plagjeogranitike ne rajonin e Tucit, Permbledhje studimesh, 43-49.

McDonough, W.F. and Frey, F.A., 1989. Rare earth elements in upper mantle rocks. In: Lipin, B.R. and McKay, G.A., eds, Geochemistry and mineralogy of rare earth elements. Mineralogical Society of America, Washington D.C., 21, 99-145.

Miyashiro, A., 1974. Volcanic rock series in island arcs and active continental margins, American Journal of Science, 274, 321-355.

Pierce, J.A., Harris, N.B.W. and Tindle, A.G., 1984. Trace element discrimination diagrams for the tectonic interpretation of granitic rocks, J. Petrology, 25, 956-983.

Reed, S.J.B., 2005. Electron Microprobe Analysis and Scanning Electron Microscopy in Geology, Cambridge University Press, 206 pp.

Robertson, A.H.F. and Shallo, M., 2000. Mesozoic-Tertiary tectonic evolution of Albania in its regional Eastern Mediterranean context, Tectonophysics, 316, 197-254.

Robinson, S.M., Kent, T.E. and Arnold, W.D., 1993. Natural Zeolites 93. In: Ming, D.W. and Mumpton, F.A., eds, International Communication of Natural Zeolites, Brockport, NY, $1995,579 \mathrm{pp}$.

Shallo, M., 1992. Geological evolution of the Albanian ophiolites and their platform periphery, Geologische Rundschau, 81(3), 681-694.

Shallo, M., 1994. Outline of the Albanian ophiolites, Ofioliti, 19, 57-75.

Shallo, M., 1995. Volcanics and sheeted dykes of the Albanian SSZ ophiolites, Bull. Shk.Gjeol., 1, 99-118

Shallo, M. and Dilek, Y., 2003. Development of the ideas on the origin of Albanian ophiolites. In: Dilek, Y. and Newcomb, S., eds, Ophiolite Concept and the Evolution of Geological Thought. Geological Society of America Sp. Paper, 373, 351-364.

Soulaymana, S.S., Mkamib, H.E. and Smith, G.M., 2004. EPR investigation of two types of Syrian's natural zeolites, J. of Physics and Chemistry of Solids, 65, 1779-1783. 